\title{
Nonsense and Wonder: An Exploration of the Prose Poems of Jeremy Over
}

\section{—'Must a name mean something?' Alice asked doubtfully.}

Many readers of poetry, especially perhaps in the UK, will look puzzled, or sniff at the very idea of a prose poem, first made popular as a form by Baudelaire's 'petit poèms on prose' in 1862. Even today, the term 'prose poem' itself still has a highly subversive ring. It defamiliarises the very notions of form and genre. The prose poem is an ideal vehicle for making the world we think we know, and indeed language itself, strange to us. It can work, as Michel Delville puts it, as 'a self-consciously deviant form [...] calling into question the naturalness of accepted boundaries between prose and poetry, the lyric and the narrative, or the literal and the figurative' (pp. 11-18). Or, as that master of the prose poem Max Jacob declared, a prose poem will open the reader's eyes 'to the absurdity of our rituals and the things we hold dear' (p. 15).

In the hands of Jeremy Over, the prose poem ${ }^{\mathrm{i}}$ has much in common with nonsense literature in its ability to combine the seemingly irreconcilable: to be at the same time comic and philosophical, lyrical and satirical, absurd and beautiful. His work lays out before us the dazzling possibilities of language. Lurking not far beneath there is also, I would say, a sense of melancholy, even when he is at his silliest.

The work of Jeremy Over has a clear lineage back to Edward Lear. Like the later Lear who mixes prose and poetry, Over has a seductively sprawling and anarchic style. Indeed many of Over's prose poems are in fact 'hybrid' poems, in which he combines pieces of prose and chopped lines within the same poem. On a brief examination of Over's biography, one might be surprised to find such an anarchist lurking within the life of a civil servant (echoes of T.S. Eliot, with a touch of Lewis Carroll?). The website of his publisher, Carcanet, tells us that he was born in Leeds in 1961 and 'studied law at Leeds University and now lives near Cockermouth in Cumbria, where he works as a policy adviser for the Department for Work and Pensions'. (In fact, he has recently taken early retirement.) Over has published two collections with Carcanet: A Little Bit of Bread and No Cheese (2001) and Deceiving Wild Creatures (2009). He is currently working on a third.

The 'hybrid' poem - the mixing of lineated and prose poetry within the same poem - is hinted at in the first stanza of 'The Poet Writes to His Family from New York', the first poem in his first book. The first three lines could be long lines of poetry or, since they come almost to the edge of the page and in the third line go over the edge (to be aligned on the right on the fourth line), could pass at first glance for prose with a ragged right margin. The last line of the first stanza, which is much shorter, could be the end of a paragraph rather than the end of a stanza:

Well here I am, alleluia - a hot pineapple on a sharp parasol!

The sea voyage was marvellous - six days of roses and cool hands.

On arriving in New York one feels a faint trace of the ink's 
but what a sky I look for and am!

desperation

(A Little Bit of Bread and No Cheese, p. 9)

Of course, we realise pretty soon that this is poetry rather than raggedy prose because many of the lines on the page turn out to be short, and because of its bouncy, exuberant rhythms: 'but what a sky / I look for / and am'. Nevertheless, we are made aware that the distinction between poetry and prose is not a clear-cut one.

Immediately apparent, of course, is the nonsense aspect I have mentioned earlier. What does Over mean when he says that he is a 'hot pineapple on a sharp parasol', that he 'feels a faint trace of the ink's desperation', and that he both looks for and is 'a sky'? What is the connection between such a bewildering array of images? Why should we concern ourselves with them? I shall briefly return to the question of why we should bother at the end of this article. In the meantime, however, I would point out that I think there is a theme running throughout Over's work: that of the difference between the literary or poetic reality we desire and the awkwardness and messiness of 'real' reality.

The reference to 'New York' in the title of this first poem gives us a good clue to Mr Over's poetic lineage. In the way he relishes and makes use of all kinds of bits of language that most of us would pay little attention to, he clearly owes something to the so-called New York School of Poets, above all John Ashbery, Kenneth Koch and Ron Padgett, who in turn took much from the Dadaists and Surrealists, who in their turn, of course, owe more than a little to Edward Lear and the tradition of nonsense verse.

John Ashbery, especially among the New York poets, is known for abrupt changes of tone within the same poem. Many of Jeremy Over's comic effects depend on similarly startling changes of tone, though in Over's case the change can also be more gradual and subtle, and built into the narrative of the poem - for Over uses just enough of a 'narrative' thread to make us think that we are reading some kind of story which we intuitively understand. His nonsense is never mere nonsense.

The hybrid poem 'Love Poem 5 a.m.' ('hybrid' being as I have stated a mixture of prose and lineated poetry) begins with a quiet, meditative, intimate voice (although the element of sendup is already present), addressing us in short, lyrical lines:

The last grains of the night

sift through the branches above our heads

as we step, on bare feet

through the young larches.

(A Little Bit of Bread and No Cheese, p. 13)

The narrator and his companion are 'too much in love to sleep'. But the poem then moves to:

weary swallows resting on the ground small hollows - pockmarks on the grass body 
of a golf course by the sea

(ibid.)

It is the word 'pockmarks' here which, with its grotesquely comic connotations, changes everything in the poem's tone. However, we are soon swept before we know it into what seems to be something from a golfing manual:

This is sometimes tricky on seaside links, of course, where the often sandy ground can drain quickly and become very firm, causing the ball to travel a long way after the first bounce. In these sorts of conditions, I always opt for the low chip and run approach myself: close the face of a seven iron slightly and just sweep the ball off the turf like you were clipping it off the dining room table. Better control and no divot.

(ibid.)

It is, of course, part of Over's strategy of seduction that he has us wondering where he is going to take us next. It can be exhilarating and liberating. We are freed from 'sense' once we realise we have been taken for a ride.

Often, as in the above, Over seems to move from cutups of other text to larger pieces of found text. By taking an existing text out of its context, and not only putting it alongside, but also connecting it to, another seemingly unrelated text, he highlights the sheer oddity of different kinds of language and demonstrates the fragility of meaning. The result, not unlike a Zen koan, provokes a realisation that not all which we take so seriously is important in the way we think it is. However, we have to be careful here when coming to an aesthetic judgement. As WH Auden warned Frank O’Hara:

'I think you must watch for what is always a great danger with any surrealistic style, namely of confusing authentic, non-logical relations which arouse wonder, with accidental ones, which arouse mere surprise and in the end fatigue.' (Joe Soap's Canoe, 12)

I hope to show here that Over does indeed succeed in 'arousing wonder'.

The two-page prose poem, 'Pendolino', the last poem in his second collection Deceiving Wild Creatures, performs a similar strategy to that of 'Love Poem 5 a.m.', moving from one narrative to a completely different one through a series of associations which Over somehow makes appear seamless to the reader. 'Pendolino' begins in banal enough fashion with the narrator sitting on a train 'with a low evening sun shining through the window'. We then learn that 'there is also rain [...] so the window is covered with raindrops that are running diagonally down the glass because of the speed of the train'. It reads like someone who is practising being a writer by observing what is around him, but who hasn't quite got the hang of it yet and has little idea of what to put in and what to leave out:

I am looking at the back seat in front of me. I don't know what it is made of - some sort of grey slightly reflective material - a kind of metal or hard plastic perhaps. The sun is shining 
through the window and onto the back of the seat so that the raindrops on the window are projected onto it - the shadows of the drops that is.

(Deceiving Wild Creatures, p. 73)

There is a feeling here of the writer trying to impose a poetic and meaningful narrative onto an awkward and untidy reality which will never fit into a story he is trying to find. He keeps us wondering where he can go next with his attempt to overcome the irreconcilability of life and literature. Although we are continually taken by surprise, the twists and turns of the narrator's thoughts trick us into believing that they are somehow inevitable.

The narrator goes on to imagine that he is watching a 'semi-abstract' film directed by Stan Brakhage, even though, as we learn, he has never actually seen one! As he studies the raindrops, he realises that they remind him of:

sperm - sperm in a hurry for something. An egg, I suppose would be normal. Only they don't look like they are searching for an egg to me. They just look like they want to escape - to flee the scene.

The back of the seat in front starts to look like a gravestone and the raindrops like words being scribbled across it. The writer begins to feel that he is getting somewhere - this is poetic stuff. But he then notices that 'the gravestone has a handhold on the aisle side, shaped a bit like a Mickey Mouse ear.' He concludes that 'A gravestone with a cartoon ear is no good to me', and instead looks out of the train window to look for inspiration there, only to be confronted by a small copse which reminds him of a woman's genitals. Feeling ashamed by this thought leads to a whole new series of questions on what might be the sources of this shame, for example even 'imagining a woman's genitals in a landscape owned by the National Trust [or] of imagining the wrong woman's genitals perhaps?' This train of thought takes us into unexpected territories. He wonders, in fact, if he is really ashamed of 'not being on a train at all now but here at my desk [...] while pretending to be sitting on a train.' In conclusion (here I am missing a few steps in the poem along the way), he asks: 'What is there to be ashamed of, after all, in trying to follow Reverdy's directions by learning "to love reality better after a long detour of dreams"?' He turns the question, seemingly, to the reader: 'I ask you. I ask you in particular', but we then learn that this 'you' is R.H. Stacey, Associate Professor of Russian Literature at Syracuse University, poised there on the back flap, perusing your own half-read book and thoughtfully smoking an unlit pipe. You look like you might know a thing or two about this'.

Somehow, in the space of two pages, we have started with one story and ended in a completely different one, and yet it all seems quite natural, quite 'real' as we are reading it. At the same time, we are thrown into the gap between narrative on the one hand and reality on the other.

As with much nonsense literature, there is something enticingly terrifying about all this as well as comical and ridiculous. Over achieves a more-intensely nonsense effect in his poem 'Daubed Loops' through a rather different technique, that of repeating 
one seemingly simple phrase in a series of variations. The sentence is taken from an autobiographical note by the German artist Gerhard Richter:

[...] as a child, after I had eaten all my food and while my supper plate was slightly greasy, I daubed loops with my finger, curves that constantly cut across each other and produced fantastic spatial structures that changed according to the light, that could be reshaped endlessly, according to the light, while the endlessly intertwining forms constantly cut across each other, and spatial structures that had eaten all my food to illustrate my plate, daubed loops in order that I as a child [...] could be supper, had eaten all my finger, slightly cut, while I daubed loops, I had eaten all my finger, and while my eaten finger could be changed, could be slightly reshaped as a finger, I daubed loops with my other finger, I changed finger and daubed loops endlessly, constantly, I daubed loops, could be curves, could be loops [...]

(A Little Bit of Bread and No Cheese, p. 41)

This is like something which starts off as practical prank and gets out of control. The effect, if you read the poem out loud, is not dissimilar to that of being spun around faster and faster. The sensation is delicious at first. Everything looks different. But after a while the giddiness makes you want to collapse and vomit. Nevertheless, once you have recovered, the temptation soon returns to start all over again - for the sheer delight of feeling giddy and seeing the world become magical in all its topsy-turvyness. Being spun around by the poem is an escape, to be sure, but it also offers a different kind of perception. Once you have fallen down and had the chance to come back to your senses, you will see the world as you know it in a fresh and grateful light.

In his five-section prose poem, 'The Irrational Element in Poetry', Over takes some sentences from an essay by Wallace Stevens, and repeats them in a way that may remind us of a dog chasing its own tail. The effect of this poem is to highlight the way in which our thought is often circular without us realising it. We believe we have moved forward and made progress, when in fact all we do is stay trapped in self-defeating, obsessive ways of thinking. The result, as always with Over, is funny yet never lets go of its sense of underlying sadness and isolation:

To begin with, I don't know. I don't know if I am competent to discuss this. I am afraid not. I don't know. Perhaps no one knows and if no one knows, perhaps it doesn't matter. It may be that someone else does know. I don't know. Does it matter? This is not the same thing as saying it does or that I do. On the one hand it does and on the other hand it doesn't. I don't know. But it really has, along with everything else, and for the most part no doubt always shall, in time, be something of that sort, for very little is ever not. I suppose I had very little in mind anyway. A kind of jotting. I should like to consider this by autumn.

(A Little Bit of Bread and No Cheese, p. 44)

This kind of repetition also clearly owes something to the prose poems of Gertrude Stein. However, the effect of Stein's work is less comical, more an investigation into the endless possibilities of what we might call 'surface reality'. Stein's poetry shows how much there is in everyday objects which is marvellous and strange, which can 
never really be captured finally in language. It does not have the same strong element of parody, and, unlike Over, does not make use of found text.

In his poem 'Wunderkammern', for example, Over appears to take sections of found prose and cut off their margins (the excerpts are centralised and tightly framed by a black rectangle so that there is no space between the words and the frame) in order to show how easily meaning can be disrupted with just a little tinkering. The effect, once more, is beautiful and comical. Here are the first two sections of a six-section poem:

Wunderkammern

1

'Sophia', the heavenly also we may mention in particular in tiers, like crinoline on iceflows or swimming thro Dürex's cornfield into and out of the petrified paper arrangement of things such as the problem squaring the concave mirror) divinity (as though upon a mountain described by Böhme as a carapace of a huge lobster divided into twelve plots in Paris, where, already our Evelyn's experience of mild frottage has become ordinary plumes outlined with a blue that even licentiousness fails 2

ong. Elsewhere a mound in
a bower of convulvulus
involves sitting somewhere
andshakingand trembling to
the music of the swamp. Just
looking at a woman is a
botany box' he claimed
simulating innocence, or
death, as well as other lines
most of them in his study
of rain or lapping waves
gladly, Another end to this
strap, tugging at an elastic
(voice: an explosive grunt
and a harp and a basket of
repetitionsanddisplacements
which are identical in size
hats off with a snowball.

(A Little Bit of Bread and No Cheese, p. 53)

I understand from Over that he has in fact edited the found text to intensify the experience he is seeking to create for the reader, namely to 'get the effect of a peephole with the language sort of half-hidden behind and extending beyond the frames. I wanted that crowded curiosity cabinet feeling,. iii As with the world through the looking glass, nothing is ever quite what it seems. 
Here I would like to return to the question I put at the beginning of this article: why should we bother with any of this. Chesterton offers a convincing defence. After differentiating between satire and nonsense, Chesterton states that nonsense literature offers an 'escape into a world in which things are not fixed horribly in an eternal appropriateness' (p. 124). That much, perhaps, is obvious, though it is a point we are continually in danger of forgetting. However, Chesterton goes on to say that the 'cosmos' is 'nonsensical also [...]. And here we fancy that nonsense will, in a very real and unexpected way, come to the aid of the spiritual view of things. Religion has for centuries been trying to make men exult in the "wonder" of creation, but they have forgotten that a thing cannot be completely wonderful so long as it remains sensible' (ibid.).

Existentially, nonsense can be seen as a way to authenticity and freedom in its resistance to common sense, or to any dominant view of what reality ultimately is (Lecercle, p.108). It keeps judgement in suspense. It also, crucially, makes us laugh. Whereas the gap between subject and object, between what one desires and what really is (which in any case is ultimately unknowable) is rendered in some sense tragic by philosophers (such as Hegel and Camus), this same gap becomes comic in nonsense literature. It is this gap which the poet Jeremy Over exploits so well.

For Over, not even surrealism can lay any claim to ultimate reality. His prose poem '.... and they lived happily until they died' parodies not only the fairy tale but also the surrealists, as if he wished to say to them, 'Don't think for a moment that you have any access to a superior world!' Surrealism may subvert our everyday sense of reality, but it can be subverted in turn, as this excerpt shows:

She knew him at once and fell weeping upon his neck. Two of her tears fell upon his eyes, which immediately grew quite clear so he could see as well as ever. Everything that he had forgotten came back [...]. On that spot a fine tree sprang up on which the bird rested, then it took them both home where they found their child grown tall and beautiful and the blockhead rode up the glass mountain and ordered more spinning wheels.

(Deceiving Wild Creatures, p. 11)

However, in showing reality in different possible lights, Jeremy Over's work can also take on a more sombre tone for example that of an autistic child in the poignant 'Tree / Bush'. Here, as acknowledged in a note at the bottom of the page, the poem relies on excerpts from Hans Asperger's paper on autism in childhood. The poem is worth quoting in its entirety:

\section{TREE / BUSH}

It can happen that three or four cross over each other so that one has a knot in one's hand. Then there is a wound there then they grow together.

STAIRS / LADDER

It is much more comfortable on the stairs than on the ladder. 


\section{STOVE / OVEN}

The stove is what one has in the room.

LAKE / RIVER

Well the lake it can never be as long and never have that many branches not in the least little bit.

\section{GLASS / WOOD}

Glass is a moss. You would have to make a hole in it unless it's a dry twig. With glass you need to hit only twice.

\section{FLY / BUTTERFLY}

The fly has wings like glass.

(Deceiving Wild Creatures, p. 33)

The effect is to show us that the world can be seen in different ways, and that there is not necessarily any 'best' or 'most real' reality. The result is astonishingly beautiful. It evokes a sense of sadness as well as a smile. But why sadness? I would say that these texts show us that our own way of perceiving reality may work much better in terms of our survival in the world, but that this perception is also in some way impoverished. Through images and language rich with association Jeremy Over empowers voices that we do not normally pay any attention to, giving us glimpses into strangely-beautiful truths, and re-awakening our buried sense of wonder.

\footnotetext{
'This article is an exploration of Over's prose poems. I should point out, however, that much of his work takes the form of lineated poems, which I plan to explore in a future article.

ii This quotation is given by Kenneth Koch in an interview with Mark Hillringhouse.

iii In an email from Jeremy Over (29 June 2015).
} 


\section{References}

\section{Primary Texts:}

Jeremy Over. 2001. A Little Bit of Bread and No Cheese. Manchester: Carcanet.

Jeremy Over. 2009. Deceiving Wild Creatures. Manchester: Carcanet.

\section{Secondary Sources:}

Chesterton, G.K. 1935. Stories, Essays and Poems. London: J.M. Dent.

Delville, M. 1998. The American Prose Poem: Poetic Form and the Boundaries of Genre. Gainsville: University Press of Florida.

Jacob, M (tr. William Kulik). 1999. The Selected Poems of Max Jacob. Oberlin College Press.

Lecercle, J.J. 1994. Philosophy of Nonsense: The Intuitions of Victorian Nonsense Literature. New York: Routledge.

Websites:

www.carcanet.co.uk

http://martinstannard.com/jsc/jsc12compressed.pdf (Joe Soap's Canoe 12)

- $\quad$ Ian Seed, 2015 